\title{
ワイヤーロープの靜的試験および繰返し引張疲労試験*
}

\author{
小西一郎**西村昭***島田喜十郎**
}

\section{Static and Pulsating Load Fatigue Tests of Wire Ropes}

by

\author{
Ichirō Konishi Akira Nishimura Kijūrō SHImadA \\ (Kyoto University) (Kobe University) (Kyoto University)
}

The objected of this experimental research was to decide the quality of several kinds of wire ropes of different sectional patterns under the static and the pulsating loads. Especially, the authors placed great emphasis on the latter case, and clarified the relations between the cycles of load repetitions and the elongation of wire ropes.

Fatigue tests were made under the pulsating tensile load of $+500 \mathrm{~kg} \sim+5000 \mathrm{~kg}$, using the Losenhausen fatigue testing machine Type UHS.

The wire ropes tested were of the following six kinds: Filler tpye of Hemp core (abbreviated to H.C.) and Rope Core (abbreviated to R.C.) ; Special Seale type of H.C. and R.C ; and Warrington type of H.C. and R.C.. The Diameter of all wire ropes was $16 \mathrm{~mm}$ in nominal size.

Measurements on the elongation of wire rope during the progress of load repetitions were taken, using the Tanabe Deflectometer, with the cyclic interval, as a rule, with 25000 cycles interval of load repetitions.

Main results obtained are as follows.

(1) The fatigue failure of wire rope occurred in the neighbourhood of the socket of alloy metal where the most remarkable twist was observed during the testing.

(2) The relation between the elongation of wire rope and the number of cycles of loading formed a line almost straight in most cases, on the semi-log graph, until the element wire failed, in which the abscissa was taken as the logarithm of the number of cycles. After the element wire failed, the elongation of the wire ropes gradually a remarkable increase, which got higher and higher showed the elongation which increased more and more until the strand failed, and they endured more than 20000 load cycles.

(3) The order of durability of the wire ropes for the repeating load of $+500 \mathrm{~kg} \sim+5000 \mathrm{~kg}$ was as follows: Special Seale type of R.C. (the best); The same of H.C.; Filler type of R.C.; The same of H.C.; Warrington type of R.C.; The same of H.C..

(4) The rate of increment of wire rope elongation accompamying the progreass of cycles of load repetitions increased as for each wire rope in the following order: Warrington type of R.C. ; Special Seale type of R.C.; Filler type of R.C. ; Special Seale type of H.C. ; Filler type of H.C. ; Warrington type of H.C..

(5) Comparing the group R.C. with that of H.C., the durability for fatigue of R.C. group was superior to that of H.C. group. On the contrary, the rate of increment of the elongation of R.C. group was inferior to that of H.C. group.

(Received Dec. 2, 1957)

\section{1. 緒}

ワイヤーロープは, 土木, 建築関係の構造执よび工 事のほかに，船舶，運搬，建設ならどに一般諸機械な ぞ各方面に，その用途は非常に広範囲にわたって和り，

* 原稿受付 昭和 32 年 12 月 2 日

** 正員 京都大学工学部

*** 正員 神戸大学工学部
ワイヤーロープの断面構造型式の種類は数十種以上に も执よんでいる。

ワイヤーロープの破断は直接重大事故の原因となる ことが多く，使用目的により破断状態が曲げ瘦労によ るもの, 静的引張により発生するもの, 回転部に用い られ摩耗が起因となって破断するもの, 繰返し引張荷 重が作用し疫労破断するものなどが考えられる。放えと 
えば，ワイヤーロープがつり橋などに使用される場合 は, 静的引張飞対する考虑のほかに交通物の通過によ り生ず台繰返し荷重に対する考慮が必要であり, 荷重 の反葆作用の絬果，もし仲びが生じた場合，主鋼索の

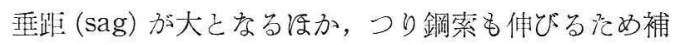

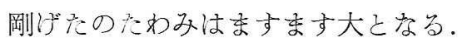

この結果, 補岡げたはついに破損するに至る。そと で, ワイヤーロープが繰返し荷重をらけそ場合, 絽返 乙回数と仙びの関係路らかにしておくことは，その 関係構造物の安全性を確保する意味で, きわわて重要 な意義がある、本研究では各種断面型式在有するワイ ヤーロープの優劣を判定するとともに, 繰返し回数と 件びの関係を究明するで, 同一綵返し引張荷重の疲 労試験圭行い, 荷重繰返し回数の進展途上の仰びの増

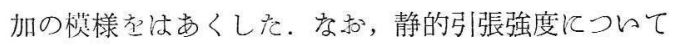
も同時に試験を行った。

\section{2. 使用試験機および供試体}

静的試験叔よひ瘦労試験は, 京都大学工学研究所に ふいて, ローゼンハウゼン疲労試験機UHS型(容量 : 静的 35 ton, 動的 20 ton) 齐用々て行った。

試験に供しでロイーロープは,フィラー型のHemp core (以下 Hemp core t H.C. と記す)のもの执よ び Rope core (以下 Rope core 苍 R.C. と記す), スペッシャルシール型の H.C. 和よび R.C., ウォーリ ントン型の H.C. 扣よび R.C.の6 種類である. ロ一 プの径法, いすれも $16 \mathrm{~mm}$ のもの䘮用いた。 供試体 はFig. 1に示すように，両端はり踓形のつかみ部支合 金により作製して，両端のソケット合金は通常の静的 引張試験に使用されるものと同様である。との場合， ワイヤーロープのソケット部は特殊な形であるそめ, 試験機への取付けの氾めに特に専用のつかみ部部品を 竹製した。

耐端ソケット合金端面間のワイヤーロープ長は，疲 労試験用供試体は $500 \mathrm{~mm}$, 静的引張試験用のものは

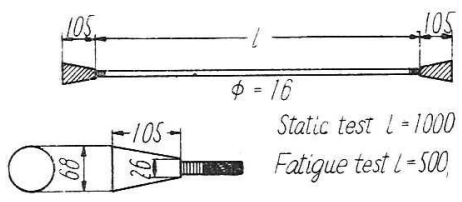

Fig. 1 From and dimensions of test specimen

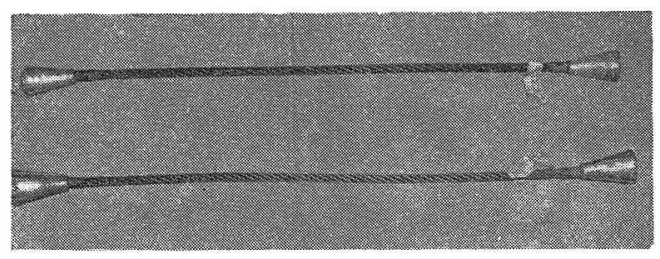

Photo. 1 Static test specimen of steel wire rope

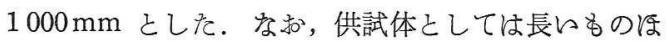
ど望ましいが，試験機取付上，上記の寸法に決定しそ。 特に前者が短いのは, ロープの变形が大となると, 試 験機油圧の pulsating 支ある限度以上に増幅しえなく なる点を考虑したものである。

\section{3. 疲労試験および伸び測定}

牧労試験に和ける試験荷重は, 全試験片につルて

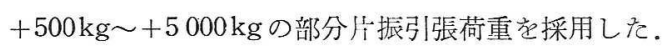

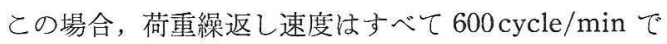
あった。

疲労試験は, 上述の繰返し荷重状態に扣ける破断ま での繰返し回数を求める活かに, 綝返し回数の進展途

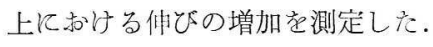

ワイヤーロープの痏労破断は，一部のストランドが 破断したときをもって判定し, そのときの荷重絽返し 数を耐久繰返し数とした。 この場合, 全部のストラン ドが破断しなくても一部が破断すると, ワイヤーロ一 プの伸びが急激に増大するそめ試験機の油圧が減少し， 安全自動制御装置により㽻労試験機は自動的に停止す る. 繰返し数が $1 \times 10^{5}$ 回飞至っても破断を生じない場 合は荷重の綝返しを中止し，ただちに静的引張試験を 行って, そのときの荷重前歴下で保有する静的引張強 度在求めた。

荷重繰返し下のワイヤーロープの伸びの測定では， 田辺式撓度振動記録器を使用して, Fig. 2 凡示した $l$ の長さの变化老測定した。この場合, ワイヤーロープ つかみ部分(図中, 斜線部分)は軟合金よりなるため, 載荷によってチ+ックがこの部分に喰い込み, それに 相当する伸びがワイヤーローブ自身の伸びに加算され

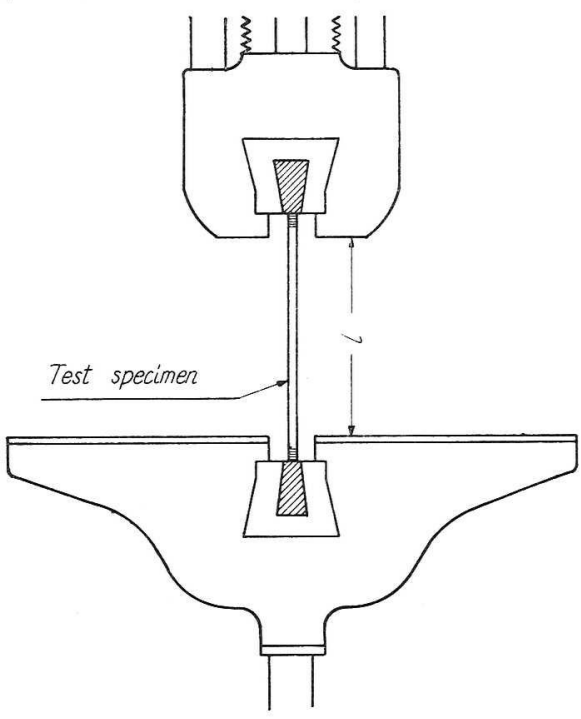

Fig. 2 Schematic diagram of the fitting of specimen to testing machine and of the measuring of elongation 
て表われるから，乙の影響をできるだけ少なくするた め飞疲労試験飞先立って静的飞 $5000 \mathrm{~kg}$ の引張力を加 えて，あらかじめチャックの喰込みを強制して，そ の後, 痩労試験を行った。伸びの変化の測定は, 原則 として繰返し数 2500 回ごとに行ら, 素線の断線開始 後はこれを 2000 回，ときには 1000 回間隔㳊短縮し た。

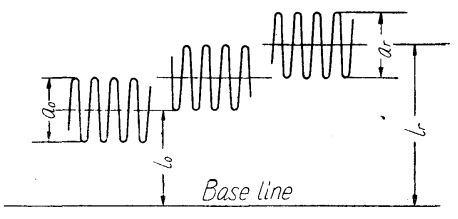

Fig. 3 Sketch of strain amplitude and elongation of wire rope under pulsating load

記録の大略は Fig. 3 のと和りで, 荷重が所定の值 $+500 \mathrm{~kg} \sim+5000 \mathrm{~kg}$ 江調整されたときの繰返し数 $n_{0}$ 回, 基線より振幅中心線洷る長さを $l_{0}$, 学 $n_{r}$ 回 飞対して $l_{r}$ である場合， $n_{r}$ 回飞和ける伸びの增加 $\Delta l$ は $\Delta l=l_{r}-l_{0}$ より求めた。 との場合の"振幅么之汁, Fig. 3 亿示す $a_{0}, a_{r}$ などのととを意味する。つぎに 素線の断線は外部々表われなかったを断線音をもっ て判定し,そのときの繰返し回数を読しで素線断線開 始数とした。

\section{4. 実 験 結 果}

瘦労試験叔よび静的引張試験結果は Table 1 亿示す とおりである。また，繰返し回数と伸び $\Delta l$ の增加と

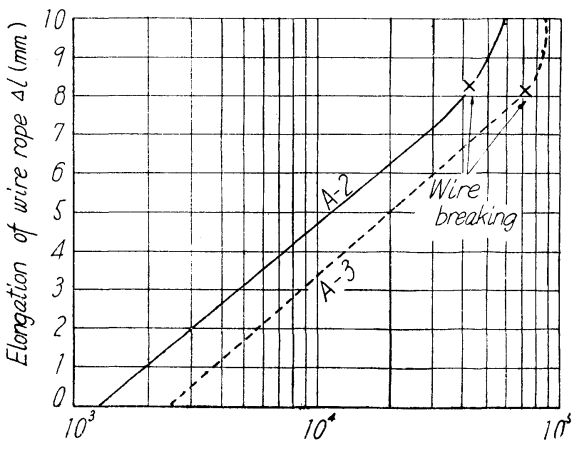

Number of load repetitions

Fig. 4 Relations between elongation and cycles of load for filler type (H.C.) wire rope

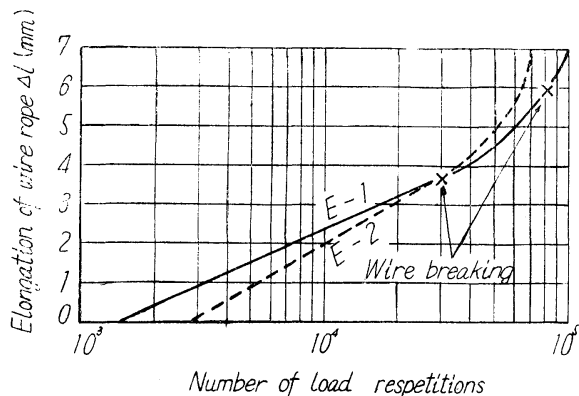

Fig. 5 Relations between elongation and cycles of load for filler type (R.C.) wire rope

の関係は，Figs. 4〜9 に示した. Table 1 に示した静

Table 1 Static and fatigue tests results of wire ropes

\begin{tabular}{|c|c|c|c|c|c|c|}
\hline Kinds of wire ropes & $\begin{array}{c}\text { Specimen } \\
\text { No. }\end{array}$ & $\left|\begin{array}{c}\text { Weight of } \\
\text { specimen } \\
(\mathrm{kg})\end{array}\right|$ & $\begin{array}{l}\text { Static } \\
\text { strength } \\
(\mathrm{kg})\end{array}$ & $\begin{array}{l}\text { Cycles } \\
\text { when wire } \\
\text { breaking } \\
\text { begin }\end{array}$ & Cycles for failure & $\begin{array}{l}\text { Remaind static strength } \\
\text { after fatigue test }\left(n=10^{5}\right) \\
(\mathrm{kg})\end{array}$ \\
\hline \multirow{3}{*}{$\begin{array}{c}\mathrm{A}+6 / 1+6+6+12 \\
\text { Filler (H.C.)* } \\
\phi 16 \mathrm{~mm}\end{array}$} & $A-1$ & $4 \cdot 43$ & \multirow{3}{*}{16000} & - & 106780 & - \\
\hline & $A-2$ & $4 \cdot 40$ & & 35680 & 56000 & - \\
\hline & $A-3$ & $4 \cdot 46$ & & 70380 & 87420 & - \\
\hline \multirow{2}{*}{$\begin{array}{c}7 \times 7+6 / 1+6+6+12 \quad 0 / 0 \\
\text { Filler (R.C.)** } \\
\phi 16 \mathrm{~mm}\end{array}$} & B-1 & $4 \cdot 40$ & \multirow{2}{*}{18550} & 81900 & No failure at $n=10^{5}$ & 13000 \\
\hline & B-2 & $4 \cdot 45$ & & 29100 & 57920 & - \\
\hline \multirow{2}{*}{$\begin{array}{c}\mathrm{A}+6 / 1+5+5+10 \quad 0 / 0 \\
\text { Special Seale (H.C.) } \\
\quad \phi 16 \mathrm{~mm}\end{array}$} & $C-1$ & $4 \cdot 35$ & \multirow{2}{*}{13750} & 55600 & 84000 & - \\
\hline & $\mathrm{C}-2$ & $4 \cdot 45$ & & 84300 & No failure at $n=10^{5}$ & 11760 \\
\hline \multirow{2}{*}{$\begin{array}{c}(\mathrm{A}+6 / 7)+6 / 1+5+5+100 / 0 \\
\text { Special Seale (R.C.) } \\
\phi 16 \mathrm{~mm}\end{array}$} & D-1 & $4 \cdot 36$ & \multirow{2}{*}{18850} & 90000 & No failure at $n=10^{5}$ & 14620 \\
\hline & $D-2$ & $4 \cdot 34$ & & 78900 & No failure at $n=10^{5}$ & 14200 \\
\hline \multirow{2}{*}{$\begin{array}{c}\mathrm{A}+6 / 1+6+6+6 \quad 0 / 0 \\
\text { Warrington (H.C.) } \\
\qquad 16 \mathrm{~mm}\end{array}$} & E-1 & $4 \cdot 32$ & \multirow{2}{*}{15250} & 48000 & 73300 & - \\
\hline & E-2 & $4 \cdot 52$ & & 27840 & 55700 & - \\
\hline \multirow{2}{*}{$\begin{array}{c}7 \times 7+6 / 1+6+6+6 \quad 0 / 0 \\
\text { Warrington (R.C.) } \\
\phi 16 \mathrm{~mm}\end{array}$} & $F-1$ & $4 \cdot 44$ & \multirow{2}{*}{18875} & 41000 & 67400 & - \\
\hline & $\mathrm{F}-2$ & $4 \cdot 34$ & & 52310 & 99800 & - \\
\hline
\end{tabular}

* (H.C.): Hemp core. *** (R.C.): Rope core. 


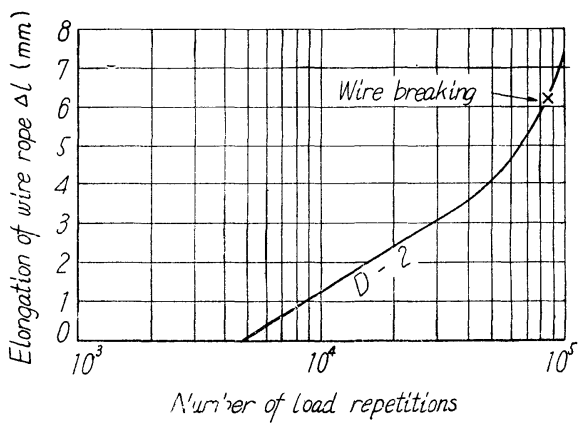

Fig. 6 Relation between elongation and cycles of load for special seale type (H.C.) wire rope

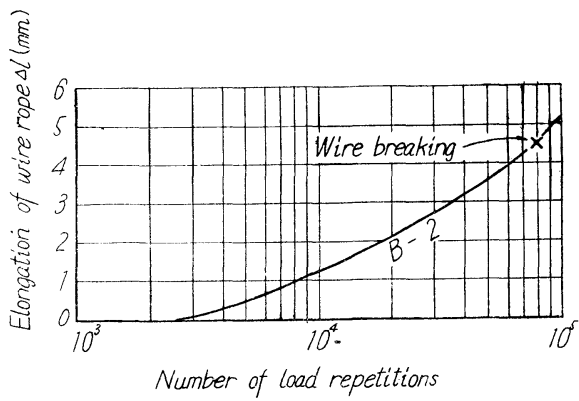

Fig. 7 Relation between elongetion and cycles of load far special seale type (R.C.) wire rope

的引張強度とは, 各グループ 2 本すつの $1000 \mathrm{~mm}$ 長 供試体につルて得られた値の平均値を表わす。ストラ ンドの断線はすべて瘦労破断に叔いては，ソケット合 金とロープとの結合部に生じ，素線の断線はすべて内 部に生じ表面からは認められなかった。

\section{5. 実験結果の考察}

ワイヤーロープの痚労試験に和レて, 供試体は荷重 繰返乙回数の增加とともに，素線間の摩擦によって相 当の発熱が生じ，それに応するようにして内部から表 面に油の侵出がみられた。

素線の破断は，すべてソケット合金との結合部に生 じそ，乙れて対して静的引張の場合は，との結合部よ り $100 \mathrm{~mm}$ あるいはそれ以上離狆を部分から破断し を、このよらな疲学破断は, ワイヤーロープのよりと 密接な関係があり，症とんぎ例外なくよりの集中を生 じた部分に和いて破断した。とこにいらよりの集中と は，荷重の繰返しによってンケット合金との結合部付 近飞集中して生ずるよりのととで，外見上あたかもワ イヤーロープの一部にゆるみ在生じているかのように 感じられる。要するに, 疲学強度に和よぼす,よりの 集中の影響は頙著なものがありよりの集中がある場 合飞は病労強度は相当低下するものと考えられ，この

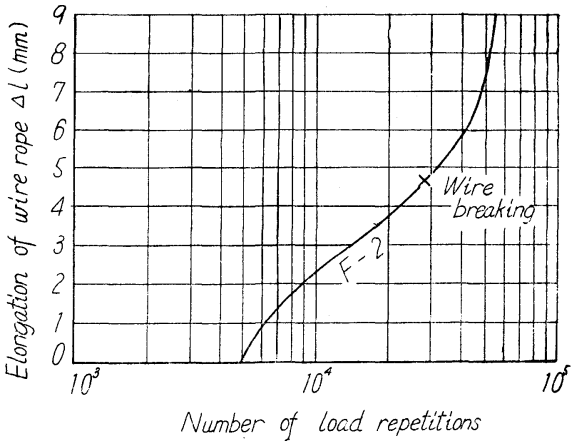

Fig. 8 Relation between elongation and cycles of load for warrington type (H.C.) wire rope

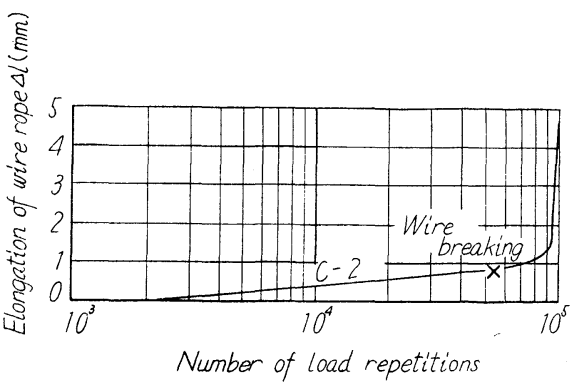

Fig. 9 Relation between elongation and cycle of load for warringation type (R.C.) wire rope

点供試体長 $500 \mathrm{~mm}$ の検討が必要である。痩学試験供 試体の作製にあてっては，かかるよりの集中をできう るかきり消滅せしめるよう留意し，かつ，ソケット合 金との結合部に生ずる応力状態の急变をできるだけ避 けうるような構造を見出すべきであると思う。

Table 1 からわかるように，ワイヤーロープの素線 に断線を生じてもストランドの破断までには約 20000 回以上の繰返し荷重に耐える。

素線に断線を生ずるまでは，仰び $\Delta l$ 汸片対数グラ フ上に扣々て繰返し数の進行とともに症直線的に増 加するが，素線が断線すると $\Delta l$ は増加する倾向を示 し始め，ストランドの破断が接近すると急激に $\Delta l$ が 増大する。また，伸び $\Delta l$ と繰返し回数の関係を普通 グラフ上にプロットすると, 素線破断点はその曲線の わん曲点となっているととが明らかて見られた。これ らより素線破断は繰返し荷重下の伸び増加に対して， 重大な影響を及ぼすととが知られる。

Table 1 加ら, 繰返し荷重 $+500 \mathrm{~kg} \sim+5000 \mathrm{~kg}$ r 対する耐久力は，スペッシャルシール R.C., 同 H.C., フィラーR.C., 同 H.C., ウォーリントン R.C., 同 H.C. の順に減少するととがわかる。

静的引張強度がだらそい同等の值を示すスペッシャ 
ルシール R.C., ウォーリントンR.C., フィラーR.C. の耐久繰返し数索比較するととにより，疲労に対する 耐久性はスペッシャルシールが最もすぐれ，疛かはで いたい同等か，あるいは，わずかスフィラーがまさる と考えられる。

次に R.C. グループと H.C. グループとの耐久繰 返し数の比較により, R.C.グループのほらが疲当に対 する耐久性がすぐれていると考えられる。るた，繰返 し回数の増加に伴う伸び $\Delta l$ の増大の割合は, Figs. 4 〜9 から明らかなように, ウォーリントン R.C., ス ペッシャルシール R.C., フィラーR.C., スペッシャ ルシールH.C., フィラーH.C., ウォーリントンH.C.の 順飞増加する。このととから R.C.グループの质らが， H.C. グループよりも伸びの增加の少ないととが明ら かである. 各断面型式の R.C.グループと H.C.グルー プの伸びの変化の状態は図からもわかるよらに，同一 グループに対してはだらそい同じよらな傾向を示して ロる.とのうち Fig. 7 のスペッシャルシール R.C.の 変化の状態が疼かの R.C.のものとやや異子った傾向 を示しているのは, Rope core の中に Hemp が入って いるためであると考えられ，乙れは H.C.グループと R.C. グループの中間的な值を示している. したがっ て,との結果よりワイヤーロープ中の Hemp は繰返 し荷重と伸びの関係に重要な影響を与えることが確認 できた，以上の点より，概して伸びの増大が割合少な らものほど, 疫労に対する耐久性がすぐれているとと がわかる。

\section{6.むす び}

以上, 各種断面型式を有するワイヤーロープの静的 試験扣よび疲労試験を行い得られを結果を要約すれば，
（1）ワイヤーロープの痩労破断の状態は，ソケッ ト合金との結合部付近によりが集中し，あたかも一部 にゆるみが生じたような状態を示しよりの集中部で 破断した。

（2）ワイヤーロープの伸び $\Delta l$ は，片対数グラフ 上に扣々て繰返し数が増すにつれてほぼ直線的に增加 する。しかし，素線が断線すると伸び $\Delta l$ 増加する 傾向を示し始め, ストランドの破断が接近すると急激 て増大する。素線が断線してからストランドが破断す るまでは約 20000 回以上の繰返し荷重に耐える。

（3）+500 kg〜+5000 kg の繰返し荷重に対与る 耐久力は, スペッシャルシール R.C., 同 H.C., フィラ - R.C., 同 H.C., ウォーリントン R.C., 同 H.C.の 順である。

（4） R.C.グループと H.C. グループにつレては, R.C.グループの在らが痚労に対する酎久性が H.C. グ ループよりすぐれている。また，伸びについては R.C. グループの病らが H.C. グループよりも伸びの増加が 少ない。この伸びの増加の状態注同一グループについ ては，ぞいたい同じような傾向起示し和り，Hemp の影響が大であることがわかった。

（5）繰返し回数の増加にともなら仲びの增加の割 合は, ウォーリントン R.C., スペッシャルシール R.C., フィラーR.C., スペッシャルシール H.C., フ ィラー H.C., ウォーリントン H.C.の順に增加する.

本研究の実験は建設省建設技術研究補助金学得て， 建設省土木研究所道路研究室長谷藤博士执よび竹内技 官の御協力のもとに行ったものである。とこに付記し て感謝の意を表する。 